\title{
BERPIKIR KREATIF DAN MOTIVASI BELAJAR \\ MELALUI PROBLEM BASED LEARNING DENGAN PEMBELAJARAN INTERAKTIF GEOGEBRA
}

\author{
Muhammad Iqbal Harisuddin, S.T, M.Pd. \\ Dosen Pendidikan Matematika STKIP Subang \\ akyssa_2@yahoo.com
}

\begin{abstract}
Creative thinking of students in learning by using a model Problem Based Learning (PBL) with multimedia GeoGebra better than using the model PBL without GeoGebra multimedia; Student motivation learning approach PBL models with multimedia GeoGebra no better than those without multimedia learning PBL models GeoGebra; Student motivation learning using multimedia model approach PBL without GeoGebra better than students whose learning using the conventional approach; Student motivation learning approach PBL models with multimedia GeoGebra better than learning to use a conventional approach; Their association (relationship) in the form of a positive relationship between students 'motivation with students' ability to think creatively, with a very high correlation coefficient. Some kerbatasan in its use is on the use of multimedia GeoGebra. This is because the learning model using multimedia GeoGebra need a better understanding of computers.
\end{abstract}

Keywords: creative thinking, problem based learning, multiedia GeoGebra, motivation to learn

\section{ABSTRAK}

Berpikir kreatif siswa dalam pembelajaran dengan menggunakan model Problem Based Learning (PBL) dengan multimedia Geogebra lebih baik dibandingkan menggunakan model PBL tanpa multimedia Geogebra; Motivasi belajar siswa pembelajarannya menggunakan pendekatan model $P B L$ dengan multimedia Geogebra tidak lebih baik dibandingkan dengan yang pembelajaran model $P B L$ tanpa multimedia Geogebra; Motivasi belajar siswa pembelajarannya menggunakan pendekatan model PBL tanpa multimedia Geogebra lebih baik dibandingkan dengan siswa yang pembelajarannya menggunakan pendekatan konvensional; Motivasi belajar siswa pembelajarannya menggunakan pendekatan model PBL dengan multimedia Geogebra lebih baik dibandingkan dengan pembelajarannya menggunakan pendekatan konvensional; Adanya asosiasi (hubungan) berupa hubungan positif antara motivasi belajar siswa dengan kemampuan berpikir kreatif siswa, dengan koefisien korelasi yang sangat tinggi. Beberapa kerbatasan dalam penggunaannya yaitu pada penggunaan 
multimedia Geogebra. Hal ini karena model pembelajaran yang menggunakan multimedia geogebra perlu pemahaman komputer yang lebih baik.

Kata kunci : berfikir kreatif, problem based learning, multiedia geogebra, motivasi belajar

\section{A. PENDAHULUAN}

Guilford dalam pidatonya yang terkenal pada tahun 1950 berupaya menarik perhatian terhadap masalah kreativitas dalam pendidikan (Munandar, 1999:9): 'yaitu bahwa pengembangan kreativitas diterlantarkan dalam pendidikan formal padahal ini amat bermakna bagi pengembangan potensi individu secara utuh dan bagi kemajuan ilmu pengetahuan dan seni budaya.' Hasil Trends in International Mathematics and Science Study (TIMSS) yang diikuti siswa Indonesia grade 8

Indonesia tahun 2011. Penilaian yang dilakukan International Association for the Evaluation of Educational Achievement Study Center Boston College tersebut, diikuti 600.000 siswa dari 63 negara. Untuk bidang Matematika, Indonesia berada di urutan ke-38 dengan skor 386 dari 42 negara yang siswanya dites. Hal ini kemungkinan disebabkan kurangnya berpikir kreatif dan motivasi belajar siswa. Selain itu juga, kemungkinan model pembelajaranya kurang mengutamakan kreativias siswa.

Prinsip belajar matematika yang dikemukakan oleh National Council of Teachers of Mathematics atau NCTM 2000 (Yaniawati, 2010:3) : belajar untuk memecahkan masalah (mathematical problem solving); belajar untuk bernalar (mathematical reasoning); belajar untuk berkomunikasi (mathematical communication); belajar untuk mengaitkan ide (mathematical connection); belajar untuk membuat representasi (mathematical represenntation). Selain itu pembentukan sifat positif terhadap matematik (positive attitude toward mathematics).

Menurut Uno (2009:23) motivasi belajar dapat timbul karena "faktor instrinsik, berupa hasrat dan keinginan berhasil dan dorongan kebutuhan belajar, harapan akan cita-cita. Faktor ekstrinsiknya adalah adanya penghargaan, lingkungan belajar yang kondusif, dan kegiatan belajar yang menarik. Motivasi belajar matematika untuk Sekolah Menengah Kejuruan (SMK) sangat rendah. Problem Based Learning (PBL) adalah salah satu model pembelajaran yang mempunyai tujuan untuk mengembangkan 'belajar aktif' di antara peserta.

Menurut Yaniawati (2010:13): "Pendidik harus memiliki wawasan dan kreativitas dalam mengembangkan model pembelajaran serta memiliki kompetensi dalam mengembangkan daya matematik siswa." Dalam hubungan ini, guru memegang peranan yang amat penting dalam menciptakan suasana pembelajaran yang baik dan dapat memotivasi siswanya. Menurut Conny Semiawan 
(dalam Amir. 2009), "pendekatan Problem Based Learning (PBL) ini bersumber dari dimensi kreatif seseorang."

Menurut Sa'ud (2011:182): "Kemajuan teknologi informasi banyak membawa dampak positif bagi kemajuan dunia pendidikan dewasa ini. Keunggulan yang ditawarkan bukan saja terletak pada faktor kecepatan untuk mendapatkan informasi namun juga fasilitas multimedia yang dapat membuat belajar lebih menarik, visual dan interaktif."

$$
\text { Perkembangan }
$$

IImu

Pengetahuan dan Teknologi sekarang ini tidak terlepas dari ilmu matematika sebagai ilmu universal. IImu matematika merupakan salah satu ilmu yang menetukan peradaban kehidupan manusia. "Mathematics is the most powerful tool we have. It controls our world. We can use it to put men on the moon. We use it to calculate how much insulin a diabetic sholud take. It is hard to get right." (Houston. 2009: ix).

Banyak sekali objek-objek matematika yang bersifat abstrak, objek geometri dan aljabar juga bersifat abstrak. Hal demikian sangat berpotensi akan memunculkan berbagai kesulitan mulai dari cara guru mejelaskan sampai siswa mempelajarinya dan memahaminya, terutama bagi siswa di kelas tingkat menengah, mengingat mereka pada umumnya masih minim dalam belajar berpikir abstrak. Menurut Piaget (Setiono. 2009), pada tahap formal operational (11 tahun ke atas) remaja mampu berpikir abstrak dan hipotesis. Fakta demikian mendorong perlunya media pembelajaran yang dapat memberikan pengalaman visual, baik ke gurunya maupun kepada siswa dalam berinteraksi dengan objek-objek geometri dan aljabar yang bersifat abstrak tersebut.

Menurut Mahmudi (2010): "Salah satu program komputer (software) yang dapat dimanfaatkan sebagai media pembelajaran matematika, khususnya geometri, adalah GeoGebra. Dengan program GeoGebra, objek-objek geometri yang bersifat abstrak dapat divisualisasi sekaligus dapat dimanipulasi secara cepat, akurat, dan efisien."

Kegunaan atau manfaat Geogebra menurut Dikovic (2009) yaitu : "Geogebra dapat membantu siswa memahami eksperimental, berorientasi pada masalah dan pembelajaran penemuan matematika di dalam kelas dan di rumah. Siswa dapat menggunakan secara bersamaan sistem aljabar komputer dan sistem geometris interaktif , maka, dengan cara ini, mereka dapat secara signifikan meningkatkan Cognitive abilities."

Menurut Wahyudin (2009:263): "Di dalam geometri, titik, garis, sinar, ruas garis, dan bidang merupakan idea (konsep) yang tidak didefinisikan. Namun demikian, kita dapat merepresentasikan (menyatakan) titik, garis, sinar, ruas garis dan bidang dalam suatu gambar." 


\section{B. LANDASAN TEORI}

1.Berpikir Kreatif

Banyak sekali teori yang berusaha menjelaskan pembentukan kepribadian kreatif, antara lain : teori Psikoanalisis, teori Humanistik, dan teori Cskiszentmihalyi. "Teori Psikoanalisis pada umumnya melihat kreativitas sebagai hasil mengatasi suatu masalah yang biasanya mulai di masa anakanak. Tindakan kreatif mentransformasi keadaan psikis yang tidak sehat menjadi sehat." (Munandar. 1999:44). Termasuk teori Psikoanalisi, yaitu:

a. Teori Freud, kemampuan kreatif merupakan ciri kepribadian yang menetap pada lima tahun pertama dari kehidupan.

b. Teori Jung, alam ketidaksadaran memainkan peranan yang amat penting dalam pemunculan kreativitas tingkat tinggi.

"Teori Humanistic melihat kreativitas sebagai hasil dari kesehatan psikologi tingkat tinggi. Kreativitas dapat berkembang selama hidup." (Munandar. 1999:47). Teori Humanistic, yaitu: Teori Rogers, menurut Carl Rogers (Munandar.1999:49) tiga kondisi internal dari pribadi yang kreatif adalah: keterbukaan terhadap pengalaman; kemampuan untuk menilai situasi sesuai dengan patokan pribadi seseorang; kemampuan untuk bereksperimen, untuk "bermain" dengan konsepkonsep.

2. Motivasi (Motivation)

Harold Koontz et al. : motivation refers to the drive and effort to satisfy a want or goal. (motivasi menunjukan dorongan dan usaha untuk memenuhi atau memuaskan suatu kebutuhan untuk mencapai suatu tujuan). (Moekijat, 1984:10). Beberapa teori-teori motivasi, diantaranya:

a. Teori Motivasi Abraham Maslow (1943-1970)

Teori motivasi menurut $\mathrm{A}$. $\mathrm{H}$. Maslow (Siagian, 2013:146) : Dasarnya semua manusia memiliki kebutuhan pokok. Lima tingkat kebutuhan itu dikenal dengan sebutan Hirarki Kebutuhan Maslow, dimulai dari tingkatan bawah yang berupa kebutuhan biologis dasar sampai motif psikologis yang lebih kompleks; yang hanya akan penting setelah kebutuhan dasar terpenuhi.

b. Achievement Theory atau Teori "Tiga Kebutuhan" (David McCleland) (1961)

Menurut David McCleland (Siagian, 2013:167-170): menyatakan bahwa ada tiga hal penting yang menjadi kebutuhan manusia, yaitu: Need for achievement (kebutuhan akan prestasi); Need for afiliation (kebutuhan akan hubungan sosial/hampir sama dengan soscialneed-nya Maslow); Need for Power (dorongan untuk mengatur).'

Beberapa indikator motivasi dalam term-term tertentu." (Makmun. 2001:40); berapa lama kemampuan penggunaan waktunya untuk melakukan kegiatan; berapa sering kegiatan dilakukan dalm periode tertentu; ketabahan, keuletan, dan kemampuannya dalam menghadapi rintangan dan kesulitan 
untuk mencapai tujuan; tingkatan aspirasinya (maksud, rencana, sasaran atau target) yang hendak dicapai dengan kegiatan yang dilakukan; tingkatan kualifikasi prestasi atau produk atau output yang dicapai dari kegiatannya (berapa banyak, memadai atau tidak); arah sikapnya terhadap sasaran kegiatan (like or dislike; positif atau negatif).

3. Model Pembelajaran Problem Based Learning

Problem Based Learning (Pembelajaran Berbasis Masalah) Menurut John dewey (David A. et.al, 2009:242) yaitu : menekankan pentingnya pembelajaran melalui pengalaman ( belajar dari pengalaman). Problem Based Learning menurut David A. et.al. (2009:242) memiliki beberapa tahap yaitu : mengidentifikasi masalah, menegaskan masalah, memilih sebuah strategi, melaksanakan strategi tersebut, mengevaluasi hasilhasil. Sedangkan menurut John Dewey Problem Based Learning ada enam langkah, yaitu: merumuskan masalah, menganalisis masalah, merumuskan hipotesis, mengumpulkan data, pengujian hipotesis, merumuskan rekomendasi pemecahan masalah.

4. Teori Belajar yang Melandasi Model Problem Based Learning

a. Teori Piaget

Piaget menerangkan inteligensi itu sendiri sebagai adaptasi biologi terhadap lingkungan. (Matlin, 2003) Piaget mengasumsikan bahwa setiap manusia itu aktif. Dalam teorinya Piaget mengemukakan bahwa kemampuan kognitif manusia berkembang menurut empat tahap, dari lahir sampai dewasa. Dan kempat tahap itu berlaku untuk setiap orang, akan tetapi usia pada saat seseorang mulai memasuki sesuatu tahap tertentu tidak selalu sama untuk setiap orang. (Matlin, 2003). Empat tahap itu adalah; Tahap sensori-motor (sensory -motor stage), Tahap pre- operasional (preoperational stage), tahap operasi konkret (concrete-operational stage), dan Tahap operasi formal (formaloperational srage). (Setiono, 2009).

b. Teori Vygotsky

Menurut teori Vygotsky, Zone of Proximal Developmnet (ZPD) merupakan celah antara actual development dan potensial development. Untuk memaksimalkan perkembangan, siswa seharusnya bekerja dengan teman yang lebih terampil yang dapat memimpin secara sistematis dalam memecahkan masalah yang lebih kompleks. (Setiono, 2009)

Teori Vygotsky yang lain adalah "scaffolding". Scaffolding merupakan suatu istilah pada proses yang digunakan orang dewasa untuk menuntun anak-anak melalui Zone of proximal developmentnya. Scaffolding adalah memberikan kepada seseorang anak sejumlah besar bantuan selama tahap - tahap awal pembelajaran dan kemudian mengurangi bantuan tersebut dan memberikan kesempatan kepada anak tersebut mengambil alih tanggung jawab yang semakin besar segera setelah ia mampu mengerjakan sendiri. (Setiono, 2009) 
c.Teori Belajar Jerome S. Bruner

Burner menganggap bahwa semua pelajaran terjadi dalam konteks kultural, dan bahwa saling keterkaitan antara individu dengan latar belakang sosial mereka sangat berpengaruh terhadap pengetahuan dan pemahaman. (Beetlestone, 2012:24). Menurut Wood bahwa Burner menggambarkan prosesproses yang berbeda yang tecakup di dalam penyelesain masalah secara kreatif. (Beetlestone, 2012:24).

5. Penjelasan Geogebra

Geogebra adalah software komputer untuk pendidikan matematika yang dapat digunakan untuk belajar (visualisasi, komputasi, ekplorasi dan eksperimen) dan mengajar materi geometri, aljabar, dan kalkulus. Menurut Velichova (2011): "Several possibilities are presented on how this useful utility might be used in elearning solutions as a dynamic interactive platform for calculations and drawings."

Program Geogebra sangat bermanfaat bagi guru maupun siswa. Menurut Dikovic (2009) : "Although Geogebra provides multiple representations of mathematical objects, it can help students is cover connections between mathematical objects and their graphical representation. Students take more responsibility for their own learning, and the dynamics of classroom activity shift to more discussion, interest, motivation to study, and cooperative learning." Interface (Tampilan Awal Geogebra)

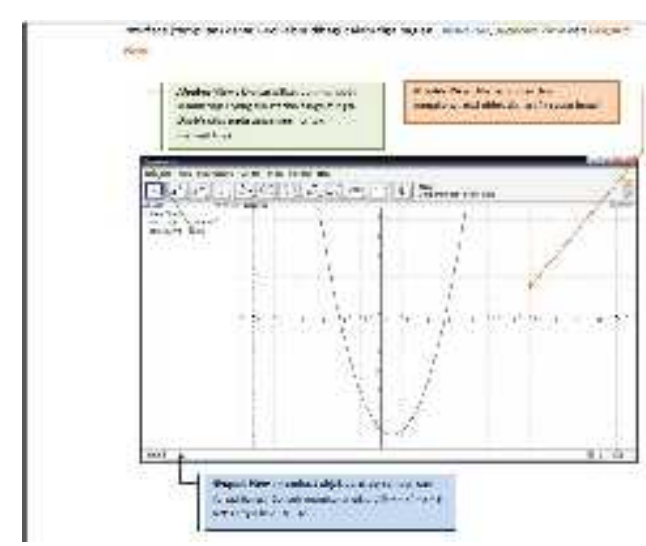

Gambar 1. Interface (Tampilan Awal Geogebra)

\section{PEMBAHASAN}

Kemampuan berpikir kreatif siswa yang pembelajarannya menggunakan pendekatan model Problem Based Learning dengan multimedia Geogebra lebih baik dibandingkan dengan pembelajaran yang menggunakan model Problem Based Learning tanpa multimedia Geogebra. Karena menurut Newby, Steppich, Lehman \& Russel (David A. et.al , 2009:254): komputer juga bisa digunakan untuk mengajarkan skill pemecahan masalah dan skill berpikir tingkat tinggi. Salah satu perwujudan dari berpikir tingkat tinggi adalah berpikir kreatif. Saat softwear pembelajaran mulai berkembang dan meluas, kemungkianan besar teknologi akan menjadi perangkat handal untuk memberikan pengalaman pemecahan masalah yang kaya dan realistis kepada siswa. (David A.et.al, 2009:254).

Siswa lebih mempunyai kemampuan memberikan macammacam penafsiran /interpretasi terhadap suatu gambar; banyak 
bertanya ketika disuruh dengan geogebra membuat bangun datar, bangun ruang, bidang, garis dan sudut, gambar yang dihasilkanyapun lebih bervariatif, kemampuan bekerja dengan cepat dan melakukan lebih banyak dari siswa lain; lebih baik dalam memilih a-simetris dalam menggambarkan atau membuat desain; serta mampu menambahkan garis-garis, warnawarna dan detail terhadap gambarnya sendiri atau gambar orang lain. Hal ini sejalan dengan David et.al. (2009:255) : Teknologi membantu guru menerapkan strategi - strategi pengajaran dengan lebih efektif. Menurut Mayer bahwa sesuatu yang baru atau yang original adalah merupakan komponen yang sangat penting didalam menumbuhkan kreativitas (Matlin, 2003). Hal ini sejalan dengan Guilford yang mengusulkan agar kreativitas dinilai dilihat dari keragaman produknya (Barsalou \& Prinz, 1997; Mayer, 1999 dalam Matlin).

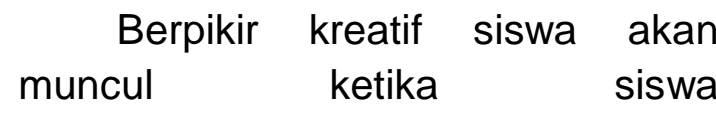
mengekspresikan imajinasinya dalam menyelesaikan masalah yang diberikan oleh guru. Sejalan dengan hal tersebut, menurut Marzano (Hassoubah, 2004) bahwa : berpikir kreatif harus Pola pikir lateral (imajinatif), seseorang berpikir tidak hanya pada bagian yang tampak dan kasat mata, tetapi juga pada bagian yang tidak terbayangkan. Mengekspresikan imajinasi pada materi geometri dengan pembelajaran model Problem Based
Learning dengan multimedia geogebra peningkatan berpikir kreatif siswanya lebih baik daripada pembelajaran konvensional. Imajinasi adalah kekuatan yang menggerakkan kreatifitas, dan penggunaan imajinasi dapat menuntun anak-anak untuk membuat koneksi yang di luar dugaan, yang tidak biasa (Beetlestone, 2012:129). Imajinasi dapat saja bisa meningkatkan proses berpikir kreatif siswa, tetapi imajinasi bisa menjadi tidak produktif apabila tidak disalurkan ke arah yang positif. Menurut pendapat Warnock (Beetlestone, 2012:129) yang mengatakan bahwa imajinasi adalah kreatif, dalam hal bahwa ia bisa membangun apa yang disukainya dari unsur- unsur yang tersedia. Menurut Beetlestone (2012:131) "Imajinasi berhubungan dengan ekspresi perasaan dan membantu menyediakan sebuah saluran keluar bagi pikiran bawah sadar, memberikan pelepasan bagi perasaan-perasaan yang tidak terekpresikan dengan cara lain."

Geogebra bisa menjadi jembatan antara dunia imajinasi dengan dunia realistis siswa. Selain itu, praktik dan latihan dengan geogebra merupakan bentuk interaksi yang digunakan untuk melatih siswa menggunakan konsep, aturan (rules), atau prosedur yang telah diajarkan sebelumnya supaya lebih terampil dalam memahami konsep. Melalui serangkaian contoh dari konsep dan pengatahuan yang dipelajari, peserta didik diberi kesempatan untuk berlatih agar terampil menerapkan konsep dan 
pengatahuan tersebut. (Yaniawati, 2010:55).

Kemampuan berpikir kreatif siswa yang pembelajarannya menggunakan pendekatan model Problem Based Learning tanpa multimedia Geogebra lebih baik dibandingkan dengan siswa yang pembelajarannya menggunakan pendekatan konvensional. Karena menurut David A. et.al. (2009:254) strategi-strategi pembelajaran model Problem Based Learning (PBL) dirancang untuk mencapai tujuantujuan yang melibatkan : skill-skill organisasional, kerja kelompok, skillskill komunikasi interpersonal, dan pengembangan tujuan-tujuan afektif seperti pemikiran- pemikiran terbuka (open mindedness) dan kesediaan (willingness).

Peningkatan motivasi belajar siswa yang pembelajarannya menggunakan pendekatan model Problem Based Learning dengan multimedia Geogebra tidak lebih baik dibandingkan dengan yang pembelajaran model Problem Based Learning tanpa multimedia Geogebra. Karena Guru perlu juga mempertimbangkan kapan saat paling sesuai atau tepat dalam memanfaatkan program Geogebra. (Mahmudi, 2010). Selain itu juga menurut Mahmudi (2010) Untuk mencapai efektivitas pembelajaran geometri, media ini perlu dikombinasikan dengan media pembelajaran lainnya, termasuk dengan media konvensional. Ketika guru tidak sesuai atau tidak tepat dalam memanfaatkan program Geogebra maka akan menimbulakan kebingungan. $A$ confusion concerning objects and algebraic variables is evident in Geogebra (Mackrell, 2011). Gerakan berbeda dari menyeret, tetapi dengan efek visual yang sama dan karenanya berpotensi membingungkan. Geogebra required a click - release move - click motion, a different motion from dragging, but with the same visual effect and hence potentially confusing (Mackrell, 2011).

Setiap individu memiliki motivasi utama berupa kecenderungan untuk percaya pada diri sendiri, memiliki rasa kebebasan dan kreativitas. Hal ini sependapat dengan McCleland menurutnya, hal penting yang menjadi kebutuhan manusia, yaitu: Need for achievement (kebutuhan akan prestasi). (Siagian, 2013:167-170). Need for Achievement (nAch), siswa ingin dipandang sebagai siswa yang berprestasi, siswa dengan nAch yang besar adalah siswa yang berusaha berbuat sesuatu lebih baik dibandingkan dengan siswa lain.

Peningkatan motivasi belajar siswa yang pembelajarannya menggunakan pendekatan model Problem Based Learning tanpa multimedia Geogebra lebih baik dibandingkan dengan siswa yang pembelajarannya menggunakan pendekatan konvensional. Karena menurut Siagian (2013:143) : "Dorongan yang berorentasi pada tindakan itulah yang sesungguhnya menjadi inti motivasi, sebab apabila tidak ada tindakan, situasi ketidakseimbangan yang dihadapi oleh seseorang tidak akan pernah 
teratasi. Hal tersebut dikuatkan dengan pendapat Pintrich \& Schunk (David A. et.al, 2009:242) : siswa memiliki tanggung jawab utama dalam menyelidiki masalah- masalah dan memburu pertanyaanpertanyaan. Tanggung jawab sangat penting, baik secara instruksional maupun secara motivasional, karena siswa dalam pelajaran-pelajaran berbasis masalah secara literal melakukan learning by doing.

Adanya asosiasi yang berupa hubungan positif interactif/resiprocal (saling mempengaruhi) antara motivasi belajar siswa dengan kemampuan berpikir kreatif siswa, dengan besarnya hubungan sangat. Karena menurut Perkins (Hassoubah, 2004) menyatakan bahwa berpikir kreatif melibatkan banyak komponen diantaranya berpikir kreatif lebih banyak bergantung kepada motivasi intrinsik daripada ekstrinsik. Hal ini sejalan dengan pendapat Marzano (Hassoubah, 2004), menurutnya : seseorang yang berpikir kreatif akan melakukan sesuatu karena dorongan internal yang akan menjadikan seseorang proaktif sehingga pikirannya mampu berkelana menembus batas-batas. Menurut Beetlestone (2012:22) bahwa penekanan Piaget pada tindakan dan penyelesaian masalah yang diarahkan oleh diri sendiri (selfdirected) mendukung pendekatan dan kegiatan-kegiatan kreatif yang melibatkan pengalaman praktis dan langsung.

Ketika siswa lebih termotivasi dalam menjawab soal yang harus menceritakan kembali, sifat kreatif itu akan timbul, sebab dalam menjawab soal-soal seperti itu siswa harus bercerita. Dan dalam bercerita itu mungkin siswa mimilih kata-kata yang tepat, menyusun kalimat yang baik dan benar, menggambar, mensinkronkan kalimat yang satu dengan kalimat yang lain, nalarnya benar, dsb. (Ruseffendi, 1991:77)

\section{KESIMPULAN}

Berpikir kreatif siswa dalam pembelajaran dengan menggunakan model Problem Based Learning (PBL) dengan multimedia Geogebra lebih baik dibandingkan menggunakan model $P B L$ tanpa multimedia Geogebra; Motivasi belajar siswa pembelajarannya menggunakan pendekatan model $P B L$ dengan multimedia Geogebra tidak lebih baik dibandingkan dengan yang pembelajaran model $P B L$ tanpa multimedia Geogebra; Motivasi belajar siswa pembelajarannya menggunakan pendekatan model $P B L$ tanpa multimedia Geogebra lebih baik dibandingkan dengan siswa yang pembelajarannya menggunakan pendekatan konvensional; Motivasi belajar siswa pembelajarannya menggunakan pendekatan model $P B L$ dengan multimedia Geogebra lebih baik dibandingkan dengan pembelajarannya menggunakan pendekatan konvensional; Adanya asosiasi (hubungan) berupa hubungan positif antara motivasi belajar siswa dengan kemampuan berpikir kreatif siswa, dengan 
koefisien korelasi yang sangat tinggi. Beberapa kerbatasan dalam penggunaannya yaitu pada penggunaan multimedia Geogebra. Hal ini karena model pembelajaran yang menggunakan multimedia geogebra perlu pemahaman komputer yang lebih baik.

\section{E. DAFTAR PUSTAKA}

Amir, M. Taufiq. 2009. Inovasi Pendidikan Melalui Problem Based Learning: Bagaimana

Pendidik Memberdayakan Pemelajar di Era Pengetahuan. Cetakan ke2. Jakarta: Kencana. Beetlestone, Florence. 2012: "Creative Learning", Strategi Pembelajaran Untuk Melesatkan

Kreatifitas Siswa. Cetakan ke- 3, Bandung: Penerbit Nusa Media.

David A Jacobsen, Paul Eggen, Donald Kauchak. 2009 " Methods For Teaching”, Cet.Ke8, Yogyakarta : Pustaka Pelajar.

Dikovic, Ljubica. 2009. Implementing Dynamic Mathematics Resources with GeoGebra at the College Level", dalam International Journal of Emerging Technologies in Learning (i-Jet), Volume 4, Issue 3, September.

Hassoubah, Z.I. (2004). Develoving Creative \& Critical Thinking Skill (Cara Berpiklr Kreatif dan Kritis). Bandung: Yayasan Nuansa Cendekia.

Houston, Kevin. 2009. How to Think Like a Mathematican: a Companion to Undergraduate Mathematics. Cambridge: Cambridge
University

Press. Http://www.geogebra.org/publicat ions/pecs 2004.pdf. Diakses tanggal 8 Pebruari 2013

Http://www.cerme7.univ.rzeszow.plW G4WG4 Mackrell.pdf. Diakses $6 / 9 / 2011$

Mahmudi, A. 2009. Mengembangan Kemampuan Berpikir Kreatif Siswa Melalui Pembelajaran Topik Pecahan. Dipresentasikan dalam Seminar Nasional Aljabar, Pengajaran Dan Terapannya dengan tema Kontribusi Aljabar dalam Upaya Meningkatkan Kualitas Penelitian dan Pembelajaran Matematika untuk Mencapai World Class University. Yogyakarta: Universitas Negeri Yogyakarta.

Mahmudi, $\quad$ A. 2010. Membelajarakan Geometri dengan Program GeoGebra. Makalah disajikan pada Seminar Nasional Matematika dan Pendidikan Matematika. Yogyakarta: Universitas Negeri Yogyakarta.

Makmun, Abin Syamsudin. 2010. Psikologi Kependidikan. Cetakan ke-4. Bandung: Remaja

Rosdakarya.

Matlin, M.W. (2003). Cognition. Fifth Edition. USA: John Wiley \& Sons, Inc. Moekijat, 1984. Dasar Dasar Motivasi. Bandung: Penerbit Sumur Bandung.

Munandar, Utami. 1999. Kreativitas dan Keberbakatan: Strategi Mewujudkan Potensi Kreatif \& Bakat. Jakarta: Gramedia 
Pustaka Utama.

Munandar, Utami. 2009.

Pengembangan Kreativitas Anak

Berbakat. Cetakan ke-3.

Jakarta : Rineka Cipta.

NCTM. (2000). The National

Council of Teacher of

Mathematics (2000). Curriculum and

Evaluation Standarts for School

Mathematics. Reston, VA.

Ruseffendi, E.T. 1991. Penilaian

Pendidikan dan Hasil Belajar

Siswa Khususnya dalam

Pengajaran Matematika. Bandung.

Setiono, Kusdwiratri. 2009. Psikologi

Perkembangan: Kajian Teori

Piaget, Selman, Kohlberg, dan

Aplikasi Riset. Bandung: Widya Padjadjaran.

Siagian, Sondang. 2013. "Teori

Motivasi \& Aplikasinya “, Rineka Cipta.

Uno, Hamzah B. 2009. Teori Motivasi \& Pengukurannya : Analisis Di Bidang Pendidikan.

Cetakan ke-5. Jakarta: Bumi Aksara.

Velichova, Daniela. 2011. "Interactive Maths with

GeoGebra", dalam International Journal of

Emerging Technologies in Learning (i-Jet), Volume 6, Special Issue 1: Vu2009", May. Wahyudin. 2010. Tinjauan Terhadap Kurikulum. Bandung: Mandiri.

Yaniawati, R. Poppy. 2010. ELearning: Alternatif Pembelajaran Kontemporer. Bandung : Arfino Raya. 